\title{
ECONOMETRIC ESTIMATION OF THE RELATIONSHIP BETWEEN THE UNEMPLOYMENT RATE AND ECONOMIC GROWTH IN LIMPOPO PROVINCE, SOUTH AFRICA
}

\author{
Tshephi Kingsley Thaba ${ }^{1 凶}$, Abenet Belete ${ }^{1}$, Johannes Jan Hlongwane ${ }^{1}$, \\ Lesetja Jacob Ledwaba ${ }^{1}$ \\ ${ }^{1}$ University of Limpopo, South Africa
}

\begin{abstract}
This study aims to empirically estimate the relationship between economic growth and the unemployment rate in the Limpopo Province of South Africa. The analysis used quarterly data covering the 2008-2018 period, which was obtained from Statistics South Africa. For data analysis, the study employed the difference model, the dynamic model and the Granger causality test to consider the potential short term and long term relationships. Based on the difference model estimation, the Okun's coefficient was determined to be -0.22 . The Granger causality test showed that a causal relationship between these two variables does not exist, which means that a change in the growth rate of the real Gross Domestic Product (GDP) does not cause a change in the rate of unemployment and vice-versa. The impossibility of applying Okun's law indicates that a cyclical recovery will not be accompanied by a decrease in unemployment. Furthermore, this might reflect the sizable structural and/or frictional component of unemployment in the Limpopo Province. Lastly, South Africa's economic policies have not been suitable for fostering development that can reduce unemployment and this could be due to an improper structure of the public and private sectors.
\end{abstract}

Keywords: economic growth, unemployment rate, Okun's coefficient, Okun's law

\section{INTRODUCTION}

Today the world faces major economic and financial problems, including challenges related to unemployment and insufficient economic growth. The increasing number of unemployed people is a hotly-debated issue all around the world, including in developed economies. Since they provide a clear picture of a country's economic development, the economic growth and unemployment rate are the key indicators that are monitored regionally and nationally by the public and policymakers alike. A widely accepted view in economics is that a higher Gross Domestic Product growth rate increases employment. This theoretical proposal, which connects GDP and unemployment is known as 'Okun's Law'. According to this law, the unemployment rate reacts more strongly to certain variations in gross domestic product evolution during recession periods. On the other hand, its value remains around natural levels during economic upswing periods. It is one of the most prominent relations in the macroeconomics theory and has been found to hold for several countries and regions, primarily in the case of developed countries (Lee, 2000; Lal, 2010; Malley and Molana, 2008).

According to Levine (2013), from a policy perspective, the level of employment depends on both the economic growth and the economy's capability to absorb labour. This means that if a country's economic growth increases considerably, it should be accompanied by an increased demand for workers. However, there is no guarantee that increased economic growth will increase labour absorption. This is partly because employers prefer

\footnotetext{
$\bowtie$ Tshephi Kingsley Thaba, Department of Languages, Social Sciences and Educational Management, University of Limpopo, Private Bag X1 106, 0727 Sovenga, South Africa, e-mail: thabakingk@gmail.com; ORCID: https://orcid.org/0000-0002-7 159-4999
} 
Thaba, T. K., Belete, A., Hlongwane, J. J., Ledwaba, L. J. (2020). Econometric estimation of the relationship between the unemployment rate and economic growth in Limpopo Province, South Africa. J. Agribus. Rural Dev., 4(58), 343-349. http://dx.doi.org/ 10.17306/J.JARD.2020.01291

capital over labour in the production process (Pierdzioch et al., 2011). Therefore, this study will contribute to the existing knowledge/literature by estimating and determining the relationship between the unemployment rate and economic growth in the Limpopo Province that significantly contributes to the national economy of South Africa. In terms of employment and output growth, the province's economy is mainly driven by four sectors, i.e. agriculture, mining, manufacturing and construction. The mining sector's contribution to the local economy has been significant in the past years and it has been playing a major role in creating jobs for the Province's citizens. According to LEDET (2018), agriculture, manufacturing and construction, respectively, have had a significant impact in terms of the overall contribution to the local economy and provincial GDP. These sectors should receive more attention in terms of industrialisation through agroprocessing facilities and industrial policies to encourage manufacturing activity due to their great potential to employ the Province's low-skilled labour force.

As of today, the relationship between the unemployment rate and economic growth in the Limpopo Province has not yet been examined as most studies focus on the national level. Banda et al. (2016) undertook a study to investigate the relationship between the unemployment rate and economic growth in South Africa in the 19942012 period. The results showed that there is a long-run relationship between the variables included, as well as a positive relationship between the GDP and the unemployment rate. Rafinandadi (2012) used the Ordinal Least Square and Threshold model to determine the relationship between output and unemployment dynamics; the findings revealed that there is a negative, nonlinear relationship between output and unemployment.

This study intends to examine this relationship, in short- and long-run, simulating the potential impact of output growth on the unemployment rate in the Limpopo Province. The study also provides important findings on the relationship between these two economic variables to enable the government to make better-informed decisions. The study reveals the reality of unemployment in the Limpopo Province through an econometric analysis, which has not been properly applied before, particularly in the case of South Africa.

\section{Okun's law}

In his study, Okun (1962) proved empirically that there exists an inverse relationship between the unemployment rate and the potential output of the US economy in the 1947-1960 period, depending on the participation in the workforce (Holmes and Silverstone, 2006). The theoretical basis of the relations examined by Okun was the assumption that an increase in the workforce must result in more goods produced and services provided. Arthur Okun found that the unemployment rate decreased in the years when the real growth rate was high and increased in the years when it remained low or even negative. The way the unemployment rate changes if the actual output deviates from the potential one was determined as well (Zangler, 2003). Okun estimated that the $\beta$ coefficient for the US economy for the 1947-1960 period was approximately 0.3 . Based on this, when the actual output is greater than $1 \%$ of the potential output, the actual unemployment rate is less than $0.3 \%$ of the natural unemployment rate.

\section{Literature review}

Christopoulos (2004) applied Okun's law at the regional level in Greece by using unit root and cointegration tests based on panel data and found that results are consistent in six out of thirteen regions examined. Sogner and Stiassny (2002) used Okun's law to analyse the Austrian economy by using the quarterly unemployment rate and GDP growth data. In this case, it was determined that Okun's coefficient was 4.16 per cent, which is almost 2 to 3 per cent initially. Javeid (2005) used Pakistan's annual time-series data for the 1981-2005 period to find links between the unemployment rate and the GDP growth - presented empirically by Arthur Okun in the early 1960s. Javied applied the difference version of Okun's law, which is more appropriate for obtaining results directly from empirical data, and used the Engle-Granger cointegration technique and Error Correction Mechanism (ECM) to find the relation of the short-term GDP behaviour to its long-run value. The results showed a negative relationship between the unemployment rate and GDP growth and both variables had a long-run relation with each other. Moreover, GDP growth moved towards equilibrium more quickly in the long run.

Ting and Ling (2011) aimed to verify the existence of Okun's relationship in the case of Malaysia's economy using the first difference and gap model with the Hodrick-Prescott filter (HP filter) followed by the Autoregressive Distributed Lag (ARDL) to determine the co-integration between the variables and their causality. The results showed that the Okun's coefficient was 
Thaba, T. K., Belete, A., Hlongwane, J. J., Ledwaba, L. J. (2020). Econometric estimation of the relationship between the unemployment rate and economic growth in Limpopo Province, South Africa. J. Agribus. Rural Dev., 4(58), 343-349. http://dx.doi.org/ 10.17306/J.JARD.2020.01291

-1.825 per cent, which is significant at a 1 per cent error level. Kreishan (2011) investigated the relationship between unemployment and economic growth in Jordan using Okun's law based on annual data covering the 1970-2008 period. The empirical results revealed that the validity of Okun's law cannot be confirmed in the case of Jordan. Thus, it can be suggested that the lack of economic growth does not explain Jordan's unemployment problem.

Phiri's (2014) study of Southern African countries covering the 2000-2013 period revealed a non-linear equilibrium between economic growth and unemployment. A momentum threshold autoregressive model was used for this purpose. Anderton et al. (2014) examined the Okun relationship for various GDP expenditure components of 17 Eurozone countries using quarterly data for the 1996-2013 period. The evidence of panel regression suggests that unemployment is particularly sensitive to movements in the GDP consumption component while those in foreign trade (exports and imports) have a much lower impact on it (Anderton et al., 2014). Apap and Gravino (2014) employed a regression analysis and found that there exists a significant negative relationship between output and unemployment in Malta. Accordingly, in the period between 1993 and 2012, the unemployment rate was more sensitive to the developments in the services sector than those in manufacturing.

\section{MATERIALS AND METHODS}

\section{Sources of data}

The study used time-series data from a period of 11 years, i.e. from the first quarter of 2008 until the fourth quarter of 2018. The total number of observations is 44 (11 years X 4). The variables used or included in the estimation of the relationship are the unemployment rate and economic growth data provided by Statistics South Africa.

\section{Analytical models}

As stated earlier, Okun's 1962 study was the first one about the relationship between output and unemployment. Okun (1962) estimated that a 1\% decrease in the unemployment rate would reduce the U.S. economy's $1947-1960$ period output by approximately $3 \%$. Okun (1962) created two models - the difference version and the dynamic version - both of which were also used in this study to analyse the Limpopo Province's economy.

\section{The difference version approach}

The study on the econometric estimation of the relationshipbetweentheunemploymentrateandeconomicgrowth in the Limpopo Province utilised the difference version of Okun's law for data analysis, as proposed by Okun (1962). This can be expressed empirically as follows:

$$
\begin{gathered}
\left(U N E M P_{t}-U N E M P_{t-1}\right)=\alpha+\beta\left(G D P_{t}-G D P_{t-1}\right)+\epsilon_{t} \\
\Delta U N E M P_{t}=\alpha+\beta \Delta G D P_{t}+\epsilon_{t}
\end{gathered}
$$

where:

$U N E M P_{t}$ - unemployment rate in $t$ period

$G D P_{t}-$ GDP growth in the $t$ period

$\epsilon_{t}$ - error term in the $t$ period

In this version, GDP growth is regressed based on unemployment rate changes; " $\beta$ " is the Okun's coefficient (the rate of change in unemployment rate due to the real output, GDP) and it can be expected to be negative because Okun proposed the existence of a negative relationship between the unemployment rate and GDP growth. This simply means that if ' $\beta$ ' is not a negative number, then the study concludes that there is no relationship, and if it is negative, then a relationship does exist. The estimated elasticity provides a measure of the relationship between the unemployment rate and economic growth, where low coefficient estimates suggest a low correlation between economic growth and unemployment rate while high estimates of the slope coefficient indicate the existence of Okun's law relationship.

\section{The dynamic version approach}

Okun (1962) noticed that the difference version is incomplete - he believed that both current and past output levels strongly affect the current unemployment rate. The dynamic version includes both the current and past GDP growth on the right side and an explanation of the variation in the current unemployment rate on the left side of the equation (Knotek, 2007). In practice, the dynamic version can be expressed as follows:

$$
\begin{gathered}
\triangle U N E M P_{t}=0+\beta_{1} G D P_{t}+\beta_{2} G D P_{t-1} \\
+\beta_{4} U N E M P_{t-1}+\epsilon_{t}
\end{gathered}
$$

where:

$\triangle U N E M P_{t-1}$ - first lag of unemployment rate

$\triangle G D P_{t-1}$ - first lag of GDP growth

In this case, $U N E M P_{t}$ and $G D P_{t}$ denote unemployment rate and GDP growth, respectively, and in this dynamic version, there are two lags concerning the GDP 
Thaba, T. K., Belete, A., Hlongwane, J. J., Ledwaba, L. J. (2020). Econometric estimation of the relationship between the unemployment rate and economic growth in Limpopo Province, South Africa. J. Agribus. Rural Dev., 4(58), 343-349. http://dx.doi.org/ 10.17306/J.JARD.2020.01291

growth and the unemployment rate which are on the right side and explain the variation in the current unemployment level (Knotek, 2007).

\section{Causality test}

A simple Granger causality model was employed as an additional model to analyse the variables which affect the relationship between the unemployment rate and economic growth in the Limpopo Province of South Africa. However, it should be noted that the term 'Granger Causality' is somewhat of a misnomer since finding 'causality' does not mean that movements in one variable cause a movement in the other, but rather causality implies a chronological ordering of movements of the series (Brooks, 2002).

$$
\begin{aligned}
& \text { UNEMP }_{t}=\alpha_{0}+\sum_{i=1}^{n} \alpha_{i} U N E M P_{t-i}+\sum_{i=1}^{n} \beta_{j} G D P_{t-j} \\
& +\mu_{1 t} \ldots \\
& G D P_{t}=\lambda_{0}+\sum_{i=1}^{n} \lambda_{i} U N E M P_{t-i}+\sum_{i=1}^{n} \delta_{j} G D P_{t-j}+\mu_{2 t} \ldots
\end{aligned}
$$

Where it is assumed that the disturbances $\mu_{1 t}$ and $\mu_{2 t}$ are uncorrelated. Equation (1) shows that the variable $U N E M P_{t}$ is determined by the lagged variable $U N E M P_{t}$ and $G D P_{t}$; the same applies to equation (2), however, the difference is that the dependent variable in equation (2) is $G D P_{t}$ and not $U N E M P_{t}$.

All $G D P_{t}$ and $U N E M P_{t}$ variables are stationary, $\mu_{1 t}$, $\mu_{2 t}$ are the disturbances satisfying the regularity assumptions of the classical linear normal regression model, and $n$ represent the optimal lag in the system. As such, $U N E M P_{t}$ does not determine $G D P_{t}$ if $\beta_{i}=0$ in (1), for any $i=1, \ldots, n$. In other words, the past values of $U N E M P_{t}$ do not provide any additional information on $G D P_{t}$ performance.

\section{RESULTS AND DISCUSSION}

Table 1 above presents the mean, standard deviation, maximum and minimum of the series. On average, the unemployment rate was $21.1 \%$ with a standard deviation of 4.19. The average real GDP growth rate was $1.89 \%$. Notably, the extreme values of all the variables are roughly close to the mean, thus exhibiting little variation or spread. The relatively low standard deviations confirm this as well. Thus, it can be concluded that no high magnitude variations in the macroeconomic variable, unemployment rate and GDP growth data examined are present.
Table 1. Statistical properties of the data

\begin{tabular}{lcc}
\hline \multicolumn{1}{c}{ Properties } & $\begin{array}{c}\text { Unemployment rate } \\
(\mathrm{Y})\end{array}$ & $\begin{array}{c}\text { Output/GDP } \\
(\mathrm{X})\end{array}$ \\
\hline Mean & 21.10 & 1.89 \\
Median & 19.85 & 1.60 \\
Maximum & 31.70 & 6.40 \\
Minimum & 15.00 & -2.20 \\
Standard Deviation & 4.19 & 1.79 \\
\hline
\end{tabular}

Source: own elaboration.

\section{Unit root test}

To statistically determine the data's stationarity properties, the ADF unit root test was applied. As part of it, the null hypothesis of unit root is rejected at the $5 \%$ significance level if the absolute value of the ADF statistic is greater than the associated critical value. Table 2 shows the results of the three ADF test series conducted as part of the study.

As shown by the results in Table 2, the unemployment rate and GDP growth rate pass the levels and become stationary at the first difference for both variables. The ADF statistics are 2.76 lower than the critical value of 2.93 in the absolute value at the levels. As a result, the study failed to reject the null hypothesis of non-stationarity at 5\% significance level. The ADF statistics for all series in the first differences are 9.94 greater than the critical value of 2.93 in the absolute value. As such, the study rejects the null hypothesis of non-stationarity in the difference series at 5\% significance level.

\section{The difference version approach}

The study on econometric estimation of the relationship between the unemployment rate and economic growth in the Limpopo Province employed the difference version of Okun's law. Table 3 below shows the empirical estimation of the results of the difference version model.

From Table 3 above the difference version results show that the GDP growth coefficient is negative at -0.22 , however, the variable is statistically insignificant at a 0.05 level with a probability value of 0.1394 . As such, the study cannot conclude whether Okun's law is applicable or not, or determine whether a relationship exists between the unemployment rate and the GDP growth rate in the case of the Limpopo Province's economy. 
Thaba, T. K., Belete, A., Hlongwane, J. J., Ledwaba, L. J. (2020). Econometric estimation of the relationship between the unemployment rate and economic growth in Limpopo Province, South Africa. J. Agribus. Rural Dev., 4(58), 343-349. http://dx.doi.org/ 10.17306/J.JARD.2020.01291

Table 2. Augmented Dickey-Fuller (ADF) test results

\begin{tabular}{lcccccc}
\hline \multirow{2}{*}{ Variables } & \multicolumn{4}{c}{ Levels } & \multicolumn{2}{c}{ First difference } \\
\cline { 2 - 7 } & Intercept & Intercept and trend & None & Intercept & Intercept and trend & None \\
\hline ADF statistics & -2.760379 & -3.073013 & -1.808543 & -9.944855 & -10.03714 & -9.746459 \\
Critical values at 5\% level & -2.931404 & -3.518090 & -1.948886 & -2.933158 & -3.520787 & -1.948886 \\
\hline & & \multicolumn{2}{c}{ Unemployment (Y)-Augmented Dickey-Fuller } \\
\hline ADF Statistics & -5.774274 & -7.567525 & -1.016303 & -9.192768 & -9.132012 & -9.268721 \\
Critical values at 5\% Level & -2.603944 & -3.518090 & -1.611711 & -2.936942 & -3.526609 & -1.949319 \\
\hline
\end{tabular}

Source: own elaboration.

Table 3. Regression output of the difference version

\begin{tabular}{lcccc}
\hline \multicolumn{1}{c}{ Variables } & Coefficient & Std. Error & t-Statistic & Prob. \\
\hline C & -0.357136 & 0.356059 & -1.003024 & 0.3217 \\
GDP & -0.224055 & 0.148631 & -1.507454 & 0.1394 \\
\hline Number of obs & 43 & & & \\
R-squared & 0.052514 & & & \\
Adjusted R-squared & 0.029405 & & & \\
F-statistic & 2.272416 & & & \\
Prob(F-statistic) & 0.139362 & & & \\
Durbin-Watson stat & 2.792594 & & & \\
\hline
\end{tabular}

Source: own elaboration.

\section{The dynamic version approach}

Based on Table 4 above, the dynamic version's results show that the GDP growth rate (DGDP), lagged GDP growth rate (DL1GDP) and lagged unemployment rate (DL1UNEMP) coefficients are consistently negative at $-0.19,-0.01$ and -0.42 , respectively. Yet, the GDP growth rate (DGDP) and lagged GDP growth rate (DL1GDP) variables are statistically insignificant at 0.25 and 0.95 probability values while the lagged unemployment rate (DL1UNEMP) is statistically significant at 0.0082 probability value.

\section{Granger causality test}

Determining the nature of the relationship between the model's variables also requires determining any potential causal links between them. For this purpose, the Granger causality test was used in the study to determine this. It makes it possible to statistically detect the cause and effect interactions between the variables in the system. Table 5 below shows the results.

Table 5 shows that in the model estimated, unidirectional Granger causality runs from the GDP growth rate to the unemployment rate. This finding is based on the fact that the null hypothesis that the GDP growth rate (GDP) does not impact the unemployment rate (UNEMP) was not rejected due to the probability value $(0.4947)$ exceeding the $5 \%$ significance level. Similarly, the null hypothesis that the unemployment rate (UNEMP) does not impact the GDP growth rate (GDP) was not rejected since the probability value of 0.1548 exceeds the $5 \%$ level of significance. Therefore, the study concluded that the change in the unemployment rate is not a predictive variable of the real GDP growth change. 
Thaba, T. K., Belete, A., Hlongwane, J. J., Ledwaba, L. J. (2020). Econometric estimation of the relationship between the unemployment rate and economic growth in Limpopo Province, South Africa. J. Agribus. Rural Dev., 4(58), 343-349. http://dx.doi.org/ 10.17306/J.JARD.2020.01291

Table 4. Regression output of the dynamic version

\begin{tabular}{lcccc}
\hline \multicolumn{1}{c}{ Variable } & Coefficient & Std. Error & t-Statistic & Prob. \\
\hline C & -0.478043 & 0.343021 & -1.393624 & 0.1715 \\
DGDP & -0.187171 & 0.160042 & -1.169508 & 0.2495 \\
DL1GDP & -0.011064 & 0.161470 & -0.068518 & 0.9457 \\
DL1UNEMP & -0.415922 & 0.148984 & -2.791728 & 0.0082 \\
\hline Number of obs & 42 & & & \\
R-squared & 0.217160 & & & \\
Adjusted R-squared & 0.155356 & & & \\
F-statistic & 3.513729 & & & \\
Prob(F-statistic) & 0.024176 & & & \\
Durbin-Watson stat & 2.093985 & & & \\
\hline
\end{tabular}

Source: own elaboration.

Table 5. Granger causality test

\begin{tabular}{ccccc}
\hline Null Hypothesis: & Obs & Lags & F-Statistic & Prob. \\
\hline GDP does not impact UNEMP & 44 & 2 & 0.7507 & 0.4947 \\
UNEMP does not impact GDP & & & 2.22110 & 0.1548 \\
\hline
\end{tabular}

Source: own elaboration.

\section{CONCLUSIONS AND RECOMMENDATIONS}

The study empirically analysed the relationship between economic growth and the unemployment rate in the case of the Limpopo Province of South Africa based on Okun's law (1962). Three types of models were used to perform the Okun's law model analysis, including the difference model, dynamic model and Granger causality test to examine the possible short- and long-term relationship between these variables. However, we found no robust evidence to link GDP growth with the unemployment rate in all the models.

The study used the difference and dynamic versions. The empirical model utilised quarterly data on the unemployment rate and the Gross Domestic Product as variables. While the difference version results show that the GDP growth coefficient is negative, the variable is statistically insignificant, and as such, it is an insignificant relationship between unemployment and GDP. The dynamic version results show that all the coefficients of all variables - including lagged variables - are negative, however, these variables are statistically insignificant. Therefore, it cannot be concluded that there exists a relationship between the unemployment rate and the GDP growth rate in the case of the Limpopo Province's economy. This means that the unemployment rate changes cannot be explained only by the GDP growth variation, but rather that other factors like using genetically-modified seeds, using machinery instead of human labour for production, etc., can also affect the unemployment rate changes while increasing the Province's GDP.

The study also utilised the Granger causality test, which indicates that a change in the unemployment rate does not cause a change in the GDP growth and vice versa. Therefore, it can be concluded that a change in the unemployment rate is not a predictive variable of the change in the actual GDP growth. Finally, the study confirmed that no evidence for a short-run causality connecting the GDP growth to the unemployment rate exists.

Based on the results of this study, it is recommended that the government and policymakers improve the 
Thaba, T. K., Belete, A., Hlongwane, J. J., Ledwaba, L. J. (2020). Econometric estimation of the relationship between the unemployment rate and economic growth in Limpopo Province, South Africa. J. Agribus. Rural Dev., 4(58), 343-349. http://dx.doi.org/ 10.17306/J.JARD.2020.01291

ways of dealing with these problems by employing economic policies that are more oriented towards structural changes and labour market transformation to supplement the existing policies like the SMME, Labour market, FDI, SDIs etc. This is because unemployment is a major impediment to social progress and results in dexterous manpower that the government has invested in being wasted.

Other policies that the government can consider to reduce unemployment include a tax reduction (the marginal tax rate (individual rate) in South Africa is as high as $40 \%$ ). The general increase in government spending could be another policy to consider, as it would boost the economy with additional funding while creating jobs and improving infrastructure at the same time. Both the Limpopo Province and the country as a whole face a major problem of structural unemployment due to a mismatch between the job requirements and the workers' skills. To improve employment opportunities, the government should initiate skill development programmes to eliminate structural unemployment. Other policies that could be adopted include employment subsidies and a reduction of trade union powers, which are significant in South Africa. Nonetheless, the youth employment subsidy initiative that is currently being debated and due to be introduced is a step in the right direction and is bound to help increase employment.

\section{SOURCE OF FINANCING}

University of Limpopo.

\section{REFERENCES}

Anderton, R., Aranki, T., Bonthuis, B., Jarvis, V. (2014). Disaggregating Okun's Law Decomposing the Impact of the Expenditure Components of GDP on Euro Area Unemployment. Eur. Cent. Bank Work. Paper Ser., 1747. Retrieved from: www.ecb.europa.eu

Apap, W., Gravino, D. (2014). Okun's Law in Malta: Lessons Learnt from a Sectoral Perspective. Min. Fin. Work. Paper Ser., 01. Retrieved from: www.mfin.gov.mt

Banda, H. (2016). The impact of economic growth on unemployment in South Africa: 1994-2012. Inv. Manag. Fin. Inn., 13(2), 246-255.

Brooks, C. (2002). Introductory econometrics for finance. Cambridge University Press.
Christopoulos, D. (2004). The relationship between output and unemployment: Evidence from Greek Regions. Stud. Reg. Sci., 83, 611-620. DOI: 10.1007/s10110-004-0198-y

Holmes, M., Silverstone, B. (2006). Okun's law, asymmetries and jobless recoveries in the United States: A Markovswitching approach. Econ. J., 92(2), 293-299.

Javeid, U. (2005). Okun's law: empirical evidence from Pakistan 1981-2005 (pp. 70-99). Unpublished Masters Thesis. Flemingsberg: Södertörn University.

Knotek, E. S. (2007). How useful is Okun's law? Econ. Rev. Feder. Res. Bank Kansas City, 92(4), 73.

Kreishan, F. (2011). Economic Growth and Unemployment: An Empirical Analysis. J. Soc. Sci., 7, 2, 228-231.

Lal, I. (2010). Test of Okun's Law in Some Asian Countries Co-Integration Approach. Eur. J. Sci. Res., 40(1), 73-80.

LEDET (Limpopo Economic Development, Environment and Tourism) (2017). Economics for the Limpopo Province, South Africa. Limpopo Province, South Africa.

Lee, J. (2000). The Robustness of Okun's Law: Evidence from OECD Countriesll. J. Macroecon., 22(2), 331-356.

Levine, L. (2013). Economic growth and unemployment rate. CRS Report for Congress 7-5700, R42063. Retrieved from: www.crs.gov

Malley, J., Molana H. (2008). Output, Unemployment and Okun's Law: Some Evidence from the G7. Econ. Lett., 101(2), 113-115.

Okun, A. (1962). Potential GNP: Its Measurement and Significance in Statistics Section? Washington DC: American Statistical Association.

Phiri A. (2014). Nonlinear co-integration between unemployment and economic growth in South Africa. Manag. Glob. Trans., 12(4), 303.

Pierdzioch, C., Rülke, J.C., Stadtmann, G. (2011). Do Professional Economists' Forecasts Reflect Okun's Law? Some Evidence for the G7 Countries. Appl. Econ., 43, 1365-1373.

Rafinandadi, A. (2012). Empirical Analysis of the Effects of Central Bank Communications on Money Market Volatility in Nigeria: 2007-2011. Unpublished Masters Thesis. Zaria: Ahmadu Bello University.

Sogner, L., Stiassny, A. (2002). An analysis on the structural stability of Okun's law. A cross-country study. Appl. Econ. Lett., 34, 1775-1787. DOI: 10.1080/ 00036840 210124180.

Ting, N.Y., Ling, L.S. (2011). Okun's law in Malaysia: an autoregressive distributed lag (ARDL) approach with Hodrick-Prescott (HP) filter. J. Glob. Bus. Econ., 2(1), 95-103.

Zagler, M. (2003). The Dynamics of Economic Growth and Unemployment in Major European Countries: Analysis of Okun's Law. Appl. Econ. Int. Dev., 3(3). 